\title{
The hidden transcripts of the slums
}

\author{
Sribas Goswami \\ Assistant Professor in Sociology, Serampore College, Dist- Hooghly, West Bengal, India, PIN-712201
}

Email address:

sribasgoswami@gmail.com

\section{To cite this article:}

Sribas Goswami. The Hidden Transcripts of the Slums. Humanities and Social Sciences. Vol. 2, No. 3, 2014, pp. 65-74.

doi: 10.11648/j.hss.20140203.13

\begin{abstract}
A slum is a compact area of overcrowded population, poorly built congested dwelling condition, unhygienic environment usually with inadequate infrastructure and lacking in proper sanitary and drinking water facilities. Living conditions in slums have a direct impact on people's health. One of the major challenges that face urban planners globally is the proliferation of slums in urban areas and the host of health hazards that they bring along with their wake. However, the prolific spread of slums has been a rampant problem in urban areas worldwide. Eventually, the extent and spread of slums in India not only help us to recognize that they are not anomalous and pathological phenomena on the urban landscape but also a manifestation of urban poverty that is still predominant in the urban economy. This study is an attempt to unfold the underlying problems of development of slums.
\end{abstract}

Keywords: Slum, Poverty, Development, Malnutrition, Infant Mortality

\section{Introduction}

The concept of a slum varies widely from country to country and depends on a variety of defining parameters. Sometimes slums are used interchangeably with squatters. In general, it is considered as a residential area in an urban locality inhabited by the very poor who have no access to tenured land of their own, and hence 'squat' on vacant land, either private or public ${ }^{1}$. For the thousands of poor in developing areas in India, especially urban areas have always been a means for improving their quality of living and environment, besides getting better jobs and incomes. This, in contrast to deteriorating conditions in the rural areas has generated a considerable flow of migrants to cities, particularly in the last three decades ${ }^{2}$. Priorities of urban migrants change over time, depending on various conditions that they find themselves. But one of the first dilemmas that slum dwellers face and which persist for a long period is the question of an adequate house. The problem is further compounded by the apathy and even antipathy of various government agencies which view the 'invasion' of urban areas by 'the masses 'and the development of slum settlements as a social 'evil' that has

\footnotetext{
${ }^{1}$ See Ramachandra, $\mathrm{P}$, "The slum: A note on facts and solutions (with special reference to grater Bombay)", 1969, pp-161-170.

2 See Sharma, R.C "Metropolitanization and Urban Crisis and Conflicts" Employment News, 1991, 30 March, New Delhi.
}

to be eradicated. Such a confusing and knee-jerk reaction and attitude towards squatter settlements has not helped the more basic question of 'adequate housing for all'. Qualifying definitions, characteristics, quality and examples of slum settlements vary widely, with the inherent danger of generalization, but an attempt has been made to identify key features which are common to such areas and distinguish them.

A slum therefore, can be defined as a residential area which has developed without legal claims to the land or permission from the concerned authorities to build; as a result of their illegal or semi-legal status, infrastructure and services are usually inadequate. There are essentially three defining characteristics which help us to understand squatter settlement: the Physical, the Social and the legal with the reasons behind them being interrelated.

a. Physical Characteristics:

A slum, due to its inbuilt 'non-legal' status, has services and infrastructure below the 'adequate' or minimum levels. Such services are important equally, network and social infrastructure, like water supply, sanitation, electricity, roads and drainage; schools, health centers, market places etc. Water supply, for example, to individual family may be absent, or a few public or community stand pipes may have been provided, using either the city networks, or a hand pump itself. Informal networks for the supply of water may also be in place. Similar arrangements 
may be made for electricity, drainage, toilet facilities etc. with little dependence on public authorities or formal channels.

b. Social Characteristics:

The households in slums belong to the lower income group, either working as wage labour or in various informal sector enterprises. On an average, most slum people earn wages at or near the minimum wage level. But household income levels can also be high due to many income earners and part-time jobs. Slum dwellers are predominantly migrants, either rural-urban or urban-urban. But many are also second or third generation squatters.

c. Legal Characteristics:

The key characteristic that delineates a slum is its lack of ownership of the 'land packet' on which poor people have built their houses. This slum could be vacant government or public land, or marginal land parcels like railway setbacks or 'undesirable' marshy land. Thus when the land is not under 'productive' used by the owner, it is appropriated by a squatter for building a house. It has to be noted here that in many parts of Raipur, a land owner may rent his land for a nominal fee to a family or families, with an informal or quasi-legal arrangement, which is not however valid under law.

It is argued that wherever there are cities there will be slums and they are associated with poverty and specific culture. Oscar Lewis (1966) who developed the notion of culture of poverty mentioned that this was not just a matter of deprivation, but a design of living with a readymade set of solutions for human problems. Hence it served a significant adaptive function. He developed this in the context of his investigations of urban Latin America and New York. He showed how culture of poverty was manifested in urban slums as a subculture. In the words of Lewis "The lack of effective participation and integration in the major institutions of the larger society is one of the crucial characteristics of the culture of poverty" (Lewis, $1966)^{3}$.

There is no consensus on a definition of urban poverty but two broad complementary approaches are prevalent: economic and sociological interpretations. Conventional economic definitions use income or consumption complemented by a range of other social indicators such as life expectancy, infant mortality, nutrition, the proportion of the household budget spent on food, literacy, school enrolment rates, access to health clinics or drinking water, to classify poor groups against a common index of material welfare (Wratten, 1995; Satterthwaite, 1995). Sociological studies of poverty have shown that people's own conceptions of disadvantage often differ from those of professional experts. Great value is attached to qualitative dimensions. More generally, there has been a widening of the debates on poverty to include more subjective

\footnotetext{
${ }^{3}$ Lewis, O. 'La Vida'. Random House, New York, 1966, Vol-421
}

definitions such as vulnerability, entitlement and social exclusion. These concepts have been useful for analyzing what increases the risk of poverty and the underlying reasons why people remain in poverty. Vulnerability is not synonymous with poverty, but refers to defenselessness, insecurity and exposure to risk, shocks and stress. Vulnerability is reduced by assets, such as human investment in health and education; productive assets including houses and domestic equipment; access to community infrastructure; stores of money, jewellery and gold; and claims on other households, patrons, the government and international community for resources at times of need (Chambers, 1995, cited by Wratten, 1995). Social exclusion is seen as a state of ill-being and disablement or disempowerment, inability which individuals and groups experience. It is manifested in 'patterns of social relationships in which individuals and groups are denied access to goods, services, activities and resources which are associated with citizenship' (ILO, $1996)^{4}$.

Most studies attempt to describe urban poverty have focused on drawing out the characteristics of urban poverty, often by comparing rural with urban poverty. However, there is still much debate as to whether urban poverty differs from rural poverty and whether policies to address the two should focus on different aspects of poverty ${ }^{5}$. In some views, rural and urban poverty are interrelated and there is a need to consider both urban and rural poverty together for they have many structural causes in common, e.g. socially constructed constraints to opportunities (class, gender) and macroeconomic policies. Many points to the important connections between the two, as household livelihood or survival strategies have both rural and urban components (Satterthwaite, 1995), (Baker, 1995) and (Wratten, 1995) ${ }^{6}$ also illustrate this point in terms of ruralurban migration, seasonal labour, remittances and family support networks. Baker (1995) illustrates how urban and rural households adopt a range of diversification strategies, by having one foot in rural activities and another in urban. Conceptualizing urban poverty as a separate category from rural poverty is also problematic because of different yardsticks for defining urban in different countries. The urban-rural divide is more a continuum rather than a rigid dichotomy.

The Raipur city is projecting immense development with sky scrapers, fancy flyovers, massive shopping malls and multiplexes. But what are co-existing are poverty, poverty of employment, poverty of shelter, poverty of basic necessities and poverty of access to basic infrastructure like

\footnotetext{
${ }^{4}$ ILO 'Social exclusion and anti-poverty strategies research findings on the patterns and causes of social exclusion and the design of policies to promote integration', 1996, Geneva.

${ }^{5}$ See the report of Dandekar V.M and N. Rath "Poverty in India", Indian School of Political Economy, 1971,P-35

${ }^{6}$ See report Wratten, E., "Urban poverty: characteristics, causes and consequences', Environment and Urbanization", 'Conceptualizing urban poverty' in IIED, 1995, Vol. 7 No. 1
} 
electricity, water, drainage and sanitation. Housing for the poor is so scarce and consequently slums are mushrooming everywhere, with little action on the part of the authorities to ensure cheap housing for the poor. The so called slum rehabilitation authority does precious little by way of locating suitable land and constructing tenements with basic necessities. Poverty can be seen in the form of slum. The development in Raipur creates a paradox; in which on the one hand Raipur is emerging with tremendous growth potential on the other hand number of urban poor is growing with heavy impetus. Slums here may be the byproduct of the development. Here the concern is to explore the development discourse in the form of slums and urban poor. Paradox of economic growth in urban areas is the growing number of urban poor. In spite of Raipur's prominent role in economy of the region, urban population and especially urban poor face serious problems in terms of access to infrastructure, diversity of livelihood opportunities, and basic services. Increasing population pressure resulting in deterioration of physical environment and quality of life further aggravates the problem ${ }^{7}$. In this study, dimensions of urban poverty and key issues for urban poor and those living in slums are discussed in detail. Present study is a humble attempt to explore some aspects of slums of Raipur city- capital of Chhattisgarh.

The present study broadly comes into the category of urban sociology where an effort is made to understand the problems of poor living slums of Raipur city. As it is known that sociology is an academic and applied discipline that studies society and human social interaction. Sociological research ranges from the analysis of short contacts between anonymous individuals on the street to the study of global social processes. It is the study of the individuals, groups and institutions and their relations that make up human society. Sociology is the study of social life, social change, and the social causes and consequences of human behavior. Sociologists investigate the structure of groups, organizations, and societies, and how people interact within these contexts. Since human behavior is shaped by social factors, the subject matter of Sociology ranges from the intimate family to the hostile mob; from organized crime to religious cults; from the divisions of race, gender and social class to the shared beliefs of a common culture; and from the Sociology of work to the sociology of sports. In fact, few fields have such broad scope and relevance for research, theory, and application of knowledge such as urban sociology. Sociology provides many distinctive perspectives on the world, generating new ideas and critiquing the old.

This study presents an overview of the slum life in Raipur. More than one third of Raipur's population resides in slums, squatters and other poor settlements. Their contribution to city's economy has been also been growing over the period. In the absence of developed land and clear

\footnotetext{
${ }^{7}$ See Gurumukhi K.T ,'Slum Related Policies and Programmes" Shelter, 2000, Vol-3, No-3p-57
}

policy to address their problems, the poor suffer from many inadequacies in terms of access to basic services, socioeconomic needs. It is necessary, therefore, to articulate policies and programmes to mainstream the slum communities with the city, both in terms of infrastructure provision and social and economic development.

\section{Growth of Raipur City and Slums}

Chhattisgarh as state came into existence in 2000 after bifurcation from Madhya Pradesh. And Raipur becomes capital of Chhattisgarh. It is evident that the new groups, who come to the city to search for entry in the development process, create a new type of residential settlement in contradiction to that of the existing urban groups. Since the new groups are mostly constituted of low-income group of rural migrants, they accept whatever accommodations are available or can be quickly stiff with waste materials or with those that can be procured on low costs on open spaces which are unusable or lying vacant. Generally the operation takes place in groups, initially consisting of relatives and kin's or members from the same caste, village, district, region or language. This process involves illegal occupancy or squatting on public or private lands. They take place independently of the authorities charged with external or institutional control of local building and planning.

Another major characteristic of these settlements is their neo-rural or village like pattern since the dwellers in these settlements follow traditional procedures with regard to building and physical development. It seems to be an attempt for reinterpretation of rural life in an urban condition. The process of formation of these autonomous squatter settlements makes it not only possible for large number of low income group families to get themselves cheap dwellings but also to supply labour force for a variety of urban activities at a lower costs. Thus the processes of producing autonomous settlements are manifestations of normal urban growth and as such the existence of these settlements is not the problem but that they are uncontrolled and their forms are often distorted. Unless there are alternatives for the millions of immigrants to live, these settlements will exist. It cannot also be assumed that unless the alternatives are found, the poor should not be really in the cities, but should wait patiently in the villages until rural and regional development policies can help them.

The inhabitants of low-income pockets in urban areas do not form a separate and distinctive social order. Studies of slums show that their composition is varied and that the slum population does maintain strong and close ties with the established formal and informal institutions of the urban system. Further these studies show the pattern of norms and values are similar to those of the larger society. In other words the urban poor including those forms the slums do not entirely belong to the informal sector and therefore cannot be regarded as a clearly distinguishable part of the urban economy. 
It is the assumption here that the slum life should be understood in its totality. The major features of slum life are its poverty and reality of this poverty is caused by and in its turn brings about a number of other socio-cultural factors. Therefore analyzing the basic features is essential to understand its links with economic, social, cultural, political institutions. Presently the focus is given on macro as well as micro level social development of slums of Raipur city. "The root cause of urban slumming seems to lie not in urban poverty but in urban wealth" (Verma, 2002).

Marginalized sections in the slum area lack essential services. The reason for this is in the unplanned and prohibited nature of these settlements. Drawing upon the history of development of a slum in the extended Raipur and, in particular, the acquisition of several services in the slum, interpretation are made about the ways in which slum communities develop an union to build their environment and obtain services. However, it is also observed that slums are homogeneous in this case in terms of physical attributes. There are vulnerable groups within a vulnerable community. In Raipur, the distinguishing feature of a slum is kutcha (semi concrete) structures, meaning those structures are mainly built of mud brick, bamboo, or thatch. The term, which derives from the word for 'crude' or 'unripe', refers to a house that is makeshift, flimsy, and unfinished, as opposed to pucca (concrete), the widely known Indian expression which derives from 'mature' or 'cooked' and which means built with good materials and designed to endure. The existing situation in Raipur with regards to land tenure in the slums, occupation and income of the slum residents, education, health, women and girls, children and adult males are understood to develop this concept. While speaking about the social development in slums multidimensional and multi-causes explanation are needed to understand the present context of Raipur city. Hence an effort is made to understand the living condition of poor people in slum areas through this study.

With the growth of trade, attention is given to the improvement of systems of communication, and mercantile activities in Raipur received a tremendous stimulus with the opening of railways and other new lines of communications. Naturally the roadways and railways for further improvements, and airport were built. It must be noted that in very recent past the business of Raipur had a very small hinterland comprising only Bilaspur, Bhilai, Nagpur, and a small part of M.P. But the establishment of iron and cement industries in Raipur and its surroundings and the opening of the new lines of communication expanded this hinterland. Nevertheless, urban growth, especially in the capital territory areas, has been exploitative and chaotic, resulting in rising unemployment and low productivity work-sharing in the informal sector, squatting in teeming slums, congestion, encroachment on public space, water and air pollution and deteriorating infrastructure and services. In this context another important aspect is that of the inequality of distribution of resources especially income which has led to the deterioration of the living standards of a section of urban people. This is one of causes of the origins of slums in the city.

Slums are scattered across the city in different wards. It is estimated that many slums are located on private lands without access to basic services. The poor, not only habitat the slums of the city but are spread in squatters and informal settlements in small groups near residential colonies, market places, industrial areas, etc., deprived of basic services. This makes them more vulnerable to vicissitudes of nature and periodic threats of eviction, ejection and demolition. Authentic data are not available on the number of such settlements and their population. Another feature is that the Raipur urban agglomeration consists of outgrowth, which is presently not part of the corporation area but inextricably linked with the city both spatially and economically. In all these areas the poor population is very high and all these areas can be considered to be slums without basic infrastructure both physical and social. The number of slums and slum population in Raipur Municipal Corporation are increasing at a faster pace over the decades. The slum population as per 2001 census is over 15, 9120. The slum population has gone up substantially over the last few years and which is very high. The urban agglomeration, with growth in population is putting heavy pressure on services and the urban local bodies are not been able to meet the demands and expectations.

\subsection{Leading Forces of Development of Raipur (Capital of Chhattisgarh State)}

\section{$>\quad$ CITY POPULATION AND ECONOMIC CHANGES \\ - Urban population is increasing rapidly \\ - Urban population soon numerically dominant \\ - Urban economic activities driving national economics \\ - Havoc changes in communication systems \\ $>$ GLOBAL ECONOMIC FACTORS \\ - Globalization \\ - Market liberalization \\ - Rapid technological change \\ - Localization \\ $>$ GLOBAL POLITICAL FACTORS \\ - Decentralization \\ - Devolution \\ - Rise of Governance- moving beyond government \\ - $\quad$ Rise of municipal civic leadership}

With the growth of trade, attention is given to the improvement of systems of communication, and mercantile activities in Raipur received a tremendous stimulus with the opening of railways and other new lines of communications. Naturally the roadways and railways for further improvements, and airport were built. It must be noted that in very recent past the business of Raipur had a very small hinterland comprising only Bilaspur, Bhilai, Nagpur, and a small part of M.P. But the establishment of iron and cement industries in Raipur and its surroundings and the opening of 
the new lines of communication expanded this hinterland. Nevertheless, urban growth, especially in the capital territory areas, has been exploitative and chaotic, resulting in rising unemployment and low productivity work-sharing in the informal sector, squatting in teeming slums, congestion, encroachment on public space, water and air pollution and deteriorating infrastructure and services. In this context another important aspect is that of the inequality of distribution of resources especially income which has led to the deterioration of the living standards of a section of urban people. This is one of causes of the origins of slums in the city. In Raipur the following reasons of growth of slums can broadly be summarized namely-

$>$ Land encroachment

$>$ Locational incompatibility

$>$ Unplanned development

$>$ Unauthorized construction

$>$ Temporary/semi-permanent structures

$>$ Absence / inadequacy of basic amenities

The key question may be asked here is why do people live in slums? Here there are two reasons for this: one is internal to the slums, and the other is external. Internal reasons include, lack of collateral assets; lack of savings and other financial assets; daily wage or low-income jobs (which in many cases are semi-permanent or temporary) ${ }^{8}$. External reasons include high cost of land and other housing services; apathy and antipathy on the part of the government to assist them; high acceptable building standards and rules and regulations; loop sided planning and zoning legislation.

\section{Objectives of Study}

The following objectives have been framed for the present study. These are follows:

1. To examine the demographic characteristics of slum dwellers.

2. To examine the nature and extent of slum and factors responsible for growth.

3. To evaluate the people's participation in slum improvement programme.

4. To know the living conditions and infrastructural facilities available in the slum areas.

5. To study the health and nutrition level of slum dwellers.

6. To explore the level of general awareness among the residents of slums.

7. To review the environmental aspects of the city.

8. To identify the problems and constraints of slum development.

\section{Methodology}

The data have been collected from secondary and primary sources.

\footnotetext{
${ }^{8}$ Herbert G, "The Urban Villagers" The free press, New York, 1961,P-15
}

A. Secondary sources: Data is collected and compiled from the books, reports, published and unpublished papers, leaflets, booklets, Municipal records and Governmental circulars.

B. Primary sources: Interviews from the field with respondents, word counselors and slum leaders have been conducted to elicit their opinions and experiences in slum life with the help of interview schedule.

\section{Sample Size}

The study was conducted on slums of the capital city of Chhattisgarh, Raipur. Total 300 families from four slums taking 95 families from Gandhi Nagar, 88 families from Moulipara, 100 families from Kushalpur and 17 families from Kota basti have taken as sample. Total surveyed population is 1383 . Head or senior most persons of the family are the respondents.

\section{Nature of Housing in the Slums}

In this part a discussion is made on the nature of housing where slum dwellers spend their day to day life. It is said that there must be an impression in the mind or gesture where we born and brought up. Sometimes man influences his surroundings and his surroundings influence him viceversa. His living in slum becomes sometime serious drawback in his life, no matter how he is eligible or talented. So here an attempt is made to discuss the direct or indirect impact of slum on human life. The slum dwellers use minimum building materials to create their living space. They use easily available local building materials. Often they use old and used tin sheets, timber rafters, joists and posts, country tiles, plastic sheets and other recycled materials. However, their limited technical expertise is put to the best creative use to meet their shelter needs. The minimum shelters of slum dwellers are not static houses. The freedom to build and meet the social and economic requirements through incremental growth is crucial to the success of the slums. This is consistently reflected in the incremental growth of dwelling units, house-groups / rows and the slum community as a whole. In Raipur slums mushroom in parts of urbanizing area with minimum of administrative control, in other words, they grow in areas which provide them with maximum of freedom to build. In the process, the slum dwellers transform most inhospitable and neglected abandoned land for housing and community building. These include land adjoining marshes, creeks, streams, drainage channels, left over spaces near transportation network of road, railways. The slumdwellers' local actions to reclaim land for their shelters and community facilities, teaches us the need for microplanning for positive use of natural resources including land, water and vegetation. Raipur city is almost unplanned city. Slums within the city can't be replaced due to many reasons. So it is obvious that development has to 
be taken up including the slum settlements.

Table 1 depicts the housing condition of slum dwellers. A clarification needs to be made about the house types or nature of the house.

$>$ Concrete/ Pucca-

Plinth: Either stone or brick with cement packing.

Wall: Either stone or brick with cement packing.

Roof: RCC/RBC

$>$ Semi-concrete/ semi pucca-

Plinth: Either stone or brick with mud packing.

Wall: Either stone or brick with mud packing.

Roof: Asbestos or tile, tin etc.

$>$ Soil made /Katcha-

Plinth: Mainly mud or mud with broken stone or brick.

Wall: Mainly mud or mud with broken stone or brick.

Roof: Bamboo, straw and cheap materials like polythene, tarpaulin etc.

$>$ Others-

All are made with temporary shed with special grass, or bamboo cutting.

According to the information available $65 \%$ slums are regularized, however, tenure security rests with few households in the regularized settlements (RMC report, 2010). Slums in Raipur urban area, as elsewhere in the state, are located on state and central government, municipal, private and other unclaimed lands. Slums are classified as objectionable and unobjectionable based on location and land use - location on riverbeds. But those who live in hazardous areas are still large. From the above table 1 it is clear that $77.67 \%$ slum dwellers reside in their own house where as $22.33 \%$ stay in houses with rent. As it has already been mentioned that these slums persist for a very long time so the house types are traditional. $27.67 \%$ respondents stay at concrete houses and $35.67 \%$ people stay in semi concrete houses. Whereas $27 \%$ people stay in soil made houses. Most of houses hare concrete and semi concrete. Only few owners of land have made temporary settlement and have given for the rent. The most of the public and private sector housing is beyond the capacity of slum- dwellers and therefore, unaffordable. The slum dwellers have their own houses in maximum cases in four slums. The nature of the houses is semi concrete type dominating the slums.

\section{Food, Nutrition and Various Issues on Health in Slums}

Having basically no education, skill and work experience, they have no choice in the competitive job market and pick up lowly paid jobs such as construction labourer, domestic servants, casual factory workers and petty trading business. With their meager income, they are forced to live in slum areas in the most unsanitary and unhygienic conditions, and are carrying out their existence with the barest necessities of life. Even if people have some money, they do not invest it in house improvement, because of its temporary status or illegal occupation of the public lands and constant threat of eviction. Therefore, the housing of the slum dwellers is of lowest quality. Poor housing conditions, overcrowded environment, poor sanitation, occupational hazards, group rivalries and clashes, stressful conditions together with lack of open space for children's recreation etc. are detrimental to the health of people in the slums. An overview of women's and children's health status presents a sobering picture. Deaths and illnesses from reproductive causes are highest among poor women particularly in slum areas. In addition to the suffering of women, yet another cause of concern is their almost apathetic attitude towards their own health and its management during illness. Girl children are found to seek treatment only when their health problem caused great physical discomfort or when it affected their work performance. The situation with respect to women's and children's health in the urban slums is no different; rather their health is neglected the most. Insecurity related to regular income, food, shelter, access to health care and other essential services, along with poverty and difficult physical and social environments, such as exploitation and abuse in the treatment of women, have an adverse impact on the health of the urban poor children.

Table 1. Ownership Status of House and Nature of House

\begin{tabular}{|c|c|c|c|c|c|c|c|c|c|c|c|c|c|}
\hline \multirow{2}{*}{$\begin{array}{l}\text { Name of } \\
\text { Slum }\end{array}$} & \multicolumn{4}{|c|}{ House holding } & \multicolumn{8}{|c|}{ Types of house } & \multirow{2}{*}{$\begin{array}{c}\text { Total } \\
\text { Respondents }\end{array}$} \\
\hline & $\begin{array}{c}\text { Own } \\
\text { house }\end{array}$ & $\%$ & $\begin{array}{l}\text { Rental } \\
\text { house }\end{array}$ & $\%$ & $\begin{array}{l}\text { Concrete } \\
\text { / Pacca }\end{array}$ & $\%$ & $\begin{array}{c}\text { Semi } \\
\text { concrete }\end{array}$ & $\%$ & $\begin{array}{l}\text { Soil } \\
\text { made }\end{array}$ & $\%$ & Others & $\%$ & \\
\hline Kota Basti & 14 & 82.35 & 3 & 17.65 & 2 & 11.77 & 6 & 35.29 & 5 & 29.41 & 4 & 23.53 & $17(100 \%)$ \\
\hline Kushalpur & 77 & 77.00 & 23 & 23.00 & 24 & 24.00 & 41 & 41.00 & 32 & 32.00 & 3 & 3.00 & $100(100 \%)$ \\
\hline Gandhinagar & 65 & 68.42 & 30 & 31.58 & 32 & 33.68 & 27 & 28.42 & 21 & 22.11 & 15 & 15.79 & $95(100 \%)$ \\
\hline Moulipara & 77 & 87.5 & 11 & 12.5 & 25 & 28.40 & 33 & 37.5 & 23 & 26.14 & 7 & 7.96 & $88(100 \%)$ \\
\hline Total & 233 & 77.67 & 67 & 22.33 & 83 & 27.67 & 107 & 35.67 & 81 & 27 & 29 & 9.66 & $300(100 \%)$ \\
\hline
\end{tabular}

Source: Personal survey:-2012 
Table 2. Consumption of Nutritious Foods by Children of slums

\begin{tabular}{|c|c|c|c|c|c|c|c|c|c|c|c|}
\hline \multirow{2}{*}{ Name of Slum } & \multicolumn{4}{|c|}{ Daily } & \multicolumn{4}{|c|}{ Some time } & \multicolumn{2}{|c|}{$\begin{array}{c}\text { Don't / Can't } \\
\text { take } \\
\end{array}$} & \multirow{2}{*}{$\begin{array}{c}\text { Total } \\
\text { Respondents }\end{array}$} \\
\hline & Milk & $\%$ & $\begin{array}{c}\text { Baby } \\
\text { food/fruits }\end{array}$ & $\%$ & Milk & $\%$ & $\begin{array}{c}\text { Baby } \\
\text { food/fruits }\end{array}$ & $\%$ & Total & $\%$ & \\
\hline Kota Basti & 3 & 17.65 & 1 & 5.88 & 3 & 17.65 & - & - & 10 & 58.82 & $17(100 \%)$ \\
\hline Kushalpur & 25 & 25.00 & 3 & 3.00 & 31 & 31.00 & 4 & 4.00 & 37 & 37.00 & $100(100 \%)$ \\
\hline Gandhinagar & 38 & 40.00 & 5 & 5.26 & 32 & 33.68 & 2 & 2.11 & 18 & 18.95 & $95(100 \%)$ \\
\hline Moulipara & 33 & 37.50 & 11 & 12.50 & 22 & 25.00 & 9 & 10.23 & 13 & 14.77 & $88(100 \%)$ \\
\hline Total & 99 & 33.00 & 20 & 6.67 & 88 & 29.33 & 15 & 5.00 & 78 & 26.00 & $300(100 \%)$ \\
\hline
\end{tabular}

Source: Personal survey:-2012

According to respondents, children are provided on an average three meals in a day. But inadequate quality and lack of diversity of food are matter of concern in food habit. Consumption pattern of slum dwellers depict that rice, potato, vegetable and edible oil are consumed on daily basis. Food composition sometimes is only rice with potato or peas or fish which are cheap to them. But access to protein rich animal product (milk and milk product, meat or chicken, eggs) is very low among the poor. According to households these are expensive food item and most of them cannot afford it. Though, a large number of households can manage fish or meat in weekly basis. $\backslash$ Most of them answer that they eat fruits $\backslash$ on weekly basis. In this case, they can afford mainly banana which is relatively cheaper than other seasonal fruits. The data show us that $33 \%$ people can afford milk for their children. But only $6.67 \%$ can daily provide nutritious foods other than milk. $29.33 \%$ children sometime take milk whereas 5\% respondents can provide fruits or baby foods seldom. Still $26 \%$ can't provide such types of foods to their children. Actually providing nutritious foods is quite expensive now a day, where half population earns less than Rs.5000/- per month and household units are more or less comprise of 5 persons per family. In Kota Basti more than 58\% respondents can't provide expensive foods to their family members. In this regard Moulipara's situation quit better than other slums.

Exclusive breastfeeding (EBF) is recommended as the optimum method of feeding for the first 6 months of life to meet the physiological requirements of the infants. It has been reported from the study that the practices of early introduction of breast feeds and late introduction of semisolids are widely prevalent, more so in slums areas. Study reveals serious erosion of breastfeeding practices. Use of pre lacteal feeds is almost universal; use of feeding bottles, animal milk, and commercial milk formulae are very common. Also it has been found that the introduction of complementary foods is markedly delayed with this background, the study have been conducted to assess the breastfeeding practices of the children in slum and to determine the factors influencing it, if any. $12.67 \%$ mother has given colostrums within 1hour. $25.67 \%$ has provided milk to their children after one hour but before 12 hours of the birth. $30.33 \%$ mother has given breastfeed within the day and $31.33 \%$ provided breastfeed after one day. In Kushalpur and Gandhinagar slums major respondents admitted that they provide breast feeding to their children after a day.

The study shows that slum dwellers often neglect minor sickness and do not consult doctor for remedy unless they fall ill. In this situation it is become obvious to know the medical practices of slum dwellers of Raipur city. Among the surveyed population (table no4) $57.33 \%$ respondents said that they consult doctor. Government hospitals provide comparatively cheaper treatment. Some of them (18.67\%) consult the local doctor or quack. But most dangerous practice is done when $22.33 \%$ respondents prescribe medicine themselves without proper knowledge. $1.67 \%$ people say that they don't take any medicine for minor cases. In Moulipara and Gandhinagar many people use this practice. Often people neglect minor sickness in slum areas which can be seen through data in the table in which Kota Basti has ranked top. In slum areas local doctors like RMP or quack are operative. They often take the chance of ignorance of slum dwellers which can be also seen in the table. In Kota Basti such cases can be seen clearly.

Table 3. Practices of Breast Feeding After the Birth of Child

\begin{tabular}{|c|c|c|c|c|c|c|c|c|c|}
\hline \multirow{2}{*}{ Name of Slum } & \multicolumn{2}{|c|}{ Within 1 hour } & \multicolumn{2}{|c|}{ Above 1 hrs to 12 hrs } & \multicolumn{2}{|c|}{ Within a day } & \multicolumn{2}{|c|}{ Above 1 day } & \multirow{2}{*}{$\begin{array}{c}\text { Total } \\
\text { Respondents }\end{array}$} \\
\hline & Total & $\%$ & Total & $\%$ & Total & $\%$ & Total & $\%$ & \\
\hline Kota Basti & 2 & 11.77 & 4 & 23.53 & 6 & 35.29 & 5 & 29.41 & $17(100 \%)$ \\
\hline Kushalpur & 17 & 17.00 & 28 & 28.00 & 12 & 12.00 & 43 & 43.00 & $100(100 \%)$ \\
\hline Gandhinagar & 7 & 7.37 & 18 & 18.95 & 37 & 38.95 & 33 & 34.73 & $95(100 \%)$ \\
\hline Moulipara & 12 & 13.64 & 27 & 30.68 & 36 & 40.91 & 13 & 14.77 & $88(100 \%)$ \\
\hline Total & 38 & 12.67 & 77 & 25.67 & 91 & 30.33 & 94 & 31.33 & $300(100 \%)$ \\
\hline
\end{tabular}

Source: Personal survey:-2012 
Table 4. Action Taken during Minor Sickness by slum dwellers

\begin{tabular}{|c|c|c|c|c|c|c|c|c|c|}
\hline Name of Slum & $\begin{array}{c}\text { Consult } \\
\text { register } \\
\text { doctor }\end{array}$ & $\%$ & $\begin{array}{c}\text { Consult } \\
\text { non-register } \\
\text { doctor }\end{array}$ & $\%$ & $\begin{array}{c}\text { Prescribe } \\
\text { himself/herself }\end{array}$ & $\%$ & $\begin{array}{c}\text { Don't } \\
\text { take any } \\
\text { action } \\
\end{array}$ & $\%$ & $\begin{array}{c}\text { Total } \\
\text { Respondents }\end{array}$ \\
\hline Kota Basti & 8 & 47.06 & 7 & 41.18 & 1 & 5.88 & 1 & 5.88 & $17(100 \%)$ \\
\hline Kushalpur & 65 & 65.00 & 25 & 25.00 & 7 & 7.00 & 3 & 3.00 & $100(100 \%)$ \\
\hline Gandhinagar & 65 & 68.42 & 8 & 8.42 & 21 & 22.11 & 1 & 1.05 & $95(100 \%)$ \\
\hline Moulipara & 34 & 38.64 & 16 & 18.18 & 38 & 43.18 & - & - & $88(100 \%)$ \\
\hline Total & 172 & 57.33 & 56 & 18.67 & 67 & 22.33 & 5 & 1.67 & $300(100 \%)$ \\
\hline
\end{tabular}

Source: Personal survey:-2012

Here in the present study table 5 shows that in some families either boys (2\%) or girls (4\%) died after birth. .67\% respondents have reported more than one infant death incidents. 93.33\% respondents don't have any such type case. It is seen that the total number of infant mortality recorded in this table is $6.67 \%$. Infant mortality is not a single problem with a single solution. Multiple and interrelated determinants interact demanding a chain of approaches and policies that to be evolved to deal with and to bring down the mortality rates. Mostly the women's and children's health is often neglected resulting poor health and development. Over population and poverty are pervasive in and causing health hazards such as mortality. Infants are naturally innocent, vulnerable and dependent on their parents mainly mother's nutrition status and child feeding practices and often suffer from viral and infectious diseases. The lower case of infant mortality shows the greater level of awareness. It is seen that among four slums Moulipara has the maximum number of infant mortality cases. But the overall scenario is encouraging in this regard.

Municipal Solid Waste (Management and Handling) Rules, 2000 says that all local bodies are expected to undertake segregation of waste and its collection, storage, transportation, processing, and disposal. Management of industrial and municipal waste is a serious challenge because of its magnitude and the resources required. The JNNURM covers programmes for urban waste disposal.

Table 6 shows that $40 \%$ respondents partially admitted that corporation dispose garbage occasionally. However, from total sample $4 \%$ respondents say that garbage is disposed regularly. The rate of generation of solid waste in these areas has outpaced population growth in recent years with the wastes normally disposed in low-lying areas of the city's outskirts. Inadequate facilities for disposal of garbage lead to large quantity of waste both ground water and surface water. Ground water contamination is less visible but often more serious. The proportion of households reporting removal of household waste by members was much higher in slum areas than that in other city areas. Only 4 per cent slum households have reported removal of their waste by local authorities and by private agreement regularly. A substantial percentage (59.09\%) of population has reported against their waste being taken to individual dumping spots. Regarding the garbage disposal provisions Kota Basti has the poor service.

Table 5. Infant Mortality Incidents in the Family of the Respondents

\begin{tabular}{|c|c|c|c|c|c|c|c|c|c|c|c|c|c|}
\hline \multirow{2}{*}{ Name of Slum } & \multicolumn{4}{|c|}{1 case } & \multicolumn{4}{|c|}{ More than 1 case } & \multicolumn{2}{|c|}{ No case } & \multirow{2}{*}{$\begin{array}{l}\text { Total mortality } \\
\text { case }\end{array}$} & \multirow{2}{*}{$\%$} & \multirow{2}{*}{ Total Respondents } \\
\hline & $\mathbf{M}$ & $\%$ & $\mathbf{F}$ & $\%$ & M & $\%$ & $\mathbf{F}$ & $\%$ & Total & $\%$ & & & \\
\hline Kota Basti & - & - & 1 & 5.88 & - & - & - & - & 16 & 94.12 & 1 & 5.88 & $17(100 \%)$ \\
\hline Kushalpur & 1 & 1.33 & 3 & 3.00 & - & - & - & - & 96 & 96.00 & 4 & 4.00 & $100(100 \%)$ \\
\hline Gandhinagar & 1 & - & 4 & 4.21 & - & - & - & - & 90 & 94.74 & 5 & 5.26 & $95(100 \%)$ \\
\hline Moulipara & 4 & 4.54 & 4 & 4.54 & 2 & 2.27 & - & - & 78 & 88.64 & 10 & 11.36 & $88(100 \%)$ \\
\hline Total & 6 & 2.00 & 12 & 4.00 & 2 & 0.67 & - & - & 280 & 93.33 & 20 & 6.67 & $300(100 \%)$ \\
\hline
\end{tabular}

Source: Personal survey:-2012

Table 6. Opinions of Slum People in Raipur about Garbage Disposal in Locality

\begin{tabular}{lccccccc}
\hline Name of Slum & Regularly & $\mathbf{\%}$ & Occasionally & $\mathbf{\%}$ & Not at all & $\mathbf{\%}$ & Total Respondents \\
\hline Kota Basti & 1 & 5.88 & 4 & 23.53 & 12 & 70.59 & $17(100 \%)$ \\
Kushalpur & 7 & 7.00 & 36 & 36.00 & 57 & 57.00 & $100(100 \%)$ \\
Gandhinagar & 2 & 2.11 & 46 & 48.42 & 47 & 49.47 & $95(100 \%)$ \\
Moulipara & 2 & 2.27 & 34 & 38.64 & 52 & 59.09 & $88(100 \%)$ \\
Total & 12 & 4.00 & 120 & 40.00 & 168 & 56.00 & $300(100 \%)$ \\
\hline
\end{tabular}

Source: Personal survey:-2012 
Table 7. Indicative Lists of Institutions and Programmes

\begin{tabular}{llll}
\hline SI. No & \multicolumn{1}{c}{ Institutions } & \multicolumn{1}{c}{ Programmes } \\
\hline & & & \multicolumn{1}{c}{ Implementation of poverty programmes } \\
Notification an de-notification
\end{tabular}

Source: - City Development Plan under JNNURM (2006-13).

Table 7 shows that several government agencies (such as Municipal Corporation, Health Department, Education Department of Chhattisgarh government) and non government organizations are working together for the betterment of slums. The table also focuses categorically on the programmes with its concern implementing institution.

Table 8. Vision for Basic Services to Urban Poor in Raipur City

\begin{tabular}{clcccc}
\hline Sl. No. & Vision Outcomes & $\mathbf{2 0 0 5 - 0 6}$ & $\mathbf{2 0 1 0}$ & $\mathbf{2 0 1 5}$ & $\mathbf{2 0 2 0}$ \\
\hline 1 & BPL Population (\%) & $33 \%$ & $15 \%$ & $20 \%$ & $10 \%$ \\
2 & Access to Schools (\%) & $40 \%$ & $60 \%$ & $80 \%$ & $100 \%$ \\
3 & Access to Primary Health Care (\%) & $65 \%$ & $80 \%$ & $100 \%$ & $100 \%$ \\
4 & Housing access (\%) & $35 \%$ & $60 \%$ & $60 \%$ & $80 \%$ \\
5 & Slum (\% reduction) & $30 \%$ & $40 \%$ & $60 \%$ & $80 \%$ \\
6 & Literacy (\%) & $45 \%$ & $65 \%$ & $80 \%$ & $100 \%$ \\
\hline
\end{tabular}

Source-CDP (2010), Raipur

Above table shows the vision of Municipal Corporation to facilitate the basic services to the urban poor. It focuses a comparative study between past and present and has set a target for future.

\section{Conclusion}

The rapid growth of urban population poses serious challenges in terms of provision of basic minimum services. Slums are an outcome of an imbalance in urban growth resulting from over-concentration of economic resources in Raipur. Slum problems are widespread and multidimensional in nature; therefore they can be solved by comprehensive programmes. Infrastructural development and civic amenities are required adequately. After bifurcation, Raipur's formation as capital has brought qualitative and quantitative changes among the slum dwellers. Environmental degradation is general phenomenon in slum. Therefore, a system has to be evolved whereby the garbage from slums can be collected from each household and placed in the nearest big garbage collection depots or transaction stations, and after that it can be cleaned by municipal services. Living conditions of urban poor in these areas are considerably meager according to the survey findings. Socio-economic status of slum dwellers is characterized as mainly low income group with inadequate education (for both parents and children). Also, poor physical environment with non-existent sufficient infrastructure is very common phenomenon in slum areas. Therefore, high prevalence of disease (waterborne) among children living in slums indicates unhealthy environment. In such circumstance, to ensure food quality of urban poor is a challenge if their socio-economic condition remains miserable. According to the information available $65 \%$ slums are regularized, however, tenure security rests with few households in the regularized settlements (RMC report).

In Raipur, substantial differences exist among mainstream and slum in terms of mobility, wealth, settlement, facilities, and standard of living etc. Although 
only a mental outlook cannot alter the structure of opportunities available, it can increase awareness, social skills, knowledge of safe spaces for meeting, and group identification. There are main issues that require attention if health services for the poor are to be improved and made more accessible - while inadequate health facilities may be partly responsible for the poor health status of slum dwellers the answer does not lie in simply providing more services.

It is evident from the study that, environmental and social conditions of the slums of Raipur city are very much deprived. In case adequate steps are not taken to prevent pollution and to improve the quality of life by providing more social amenities, the life of the slum dwellers of the city may become more miserable, and this may be the cause of health hazards and worst devastation. Regarding garbage disposal system Raipur city is facing tremendous problem particularly in these slum areas. Since most of the slums are located in marginal areas encroaching on drains, the physical environment in most of these is of poor quality. The other main problem is lack of covered drains and sewerage facility. The conditions of public toilets constructed under different schemes are in poor state, as there is lack of maintenance by the assigned staff and as a result, they are not used.

\section{References}

[1] Abrams, C 1964. "Man's Struggle for the Shelter in an Urbanizing World", M.I.T Press, Cambridge.

[2] Banerjee, B 1986. "Rural to Urban Migration and the Urban Labor Market”, Himalaya Publishing House, Delhi.

[3] Baker, J. 1995. 'Survival and accumulation strategies at the rural-urban interface in north-west Tanzania: Urban poverty: Characteristics, causes and consequences', Environment and Urbanization, IIED Vol. 7 No 1.

[4] Desai, A.R \& Pillai S.D, 1970. "Slums and Urbanization", Popular Prakashan, Bombay.

[5] Goswami, S and Manna, S, 2010. "Social aspects of environment: A study of slums of Raipur city", Man and Life, January-June Vol-36 1\&2, Bidisha, India.
[6] Khan, M. H and Kraemer, A. 2008. "Socio-economic factors explain differences in public health-related variables among women in Bangladesh: A cross-sectional study" (BMC Public Health. 2008; 8: 254. Published online 2008 July 23.

[7] Lewis, O. 1966. 'La Vida'. Random House, New York, Vol421.

[8] Mitra, A. 1994. "Urbanization, Slums, Informal Sector Employment and Poverty: An Exploratory Study", B. R. Publishing Corporation, Delhi.

[9] Ramachandra, P 1970. "The slums: A note on facts and solution in slums cities of Madhya Pradesh". Popular Prakashan, Bombay.

[10] Saxena, M.H 1987. "The problem of slums in small towns: A case study of Shrirangapur", Concept Publishing Company, New Delhi.

[11] Shetty, S.L (2003). "Growth of SDP and Structural Changes in State Economies: Inter-State Comparisons", EPW, Vol. 38, No 49, December 6, pp5189-5200

[12] Shaban, A (2002). "Growth and Disparities of Incomes Across States", Man and Development, Centre for Research in Rural and Industrial Development, Chandigarh.

[13] Singh, Nirvikar, L. Bhanadari, A, Chen and A. Khare (2003). "Regional Inequality in India: A Fresh Look", EPW,Vol 38, No 11, March 15, pp 1069-1073

[14] Sundaram, K and Tendulkar S.D (2003). "Poverty in India in the 1990s", EPW, Vol. 38, No 14, april 5, pp 1385-1394.

[15] Sundar, R and Sharma (2002). "A Morbidity and Utilisation of Healthcare Services: A Survey of Urban Poor in Delhi and Chennai" Economic and Political Weekly, Vol. 37, No. 47.

[16] Verma, G. D.2002. 'Slumming India: A Chronicle of Slums and Their Saviours', Penguin Books India.

[17] Wasserman, S and Faust, K 1994. "Social Network Analysis", Cambridge", U.K.

[18] Wratten, E 1995. "Urban poverty: characteristics, causes and consequences', Environment and Urbanization", 'Conceptualizing urban poverty' in IIED, Vol. 7 No 1.

[19] World Food Programme (WFP) (2002). "Food Security Assessment in Bangladesh, Issues and Implications for Mapping Food Insecurity and Vulnerability, Vulnerability Analysis and Mapping", Bangladesh. 